\title{
Creating e-confidence in schools
}

\author{
Brian Samways \\ Past Chairman of IFIP Technical Committee for Education (TC3) c/o Martineau Education \\ Centre, Balden Road, Birmingham, B32 2EH, United Kingdom.
}

brian_samways@birmingham.gov.uk

Abstract: In today's world of advancing technologies, we must continually ask, "What are the benefits to the Learners?" Over the last decade ICT (Information and Communication Technologies) have moved from A) 'Liberating the Learner" to B) "Networking the Learner" and now as communications and the internet are becoming invisible to the user, to C) "The Learner at the Centre". The process is being accelerated by governments around the world providing learners with faster and faster access to the world wide web and many have set high targets for years 2004 and 2005 in terms of the number of connections and the curriculum that should be taught. But if youngsters seem to cope so easily with ICT why can't our teachers? As nations we must continue to train our teachers, provide more classroom support and ensure that newly-qualified teachers entering the profession are competent. Hence we move to an ICT competent profession. A teacher's role will be to advise on various networks of learning and knowledge and to prepare pupils to "manage their learning". Learning opportunities will be available 24 hours a day on-line together with an on-line teacher, tutor or mentor. Schools will become the local hub of lifelong learning, bringing together parents, local residents and public agencies to offer community-wide learning opportunities.

Key words: community learning, home learning, learning culture, Lifelong Learning 


\section{INTRODUCTION}

Often much can be learnt by looking back at History, though sometimes what one sees is very worrying to particular individuals. In the 15th Century in Europe, the printing press arrived and many a religious worker saw their role as writer and copier of manuscripts, under threat from the new machines. A similar thing happened in the 19th Century with the invention of the steam engine and the introduction of machines into factories. The story continues into the 20th Century (certainly in the UK) with the decrease in the need for cotton mills and coal miners, and then the reduction in agricultural labour, partly due to the introduction of machinery and partly due to cheaper production in other countries. Then came the turn of the fishermen; they saw their 'catch quota' limited by legislation, resulting in a reduction in the numbers employed. Could it be that the 'teaching' profession is next?

In today's world of advancing technologies, we must continually ask "What are the benefits to the Learners?" Within IFIP, our World Conferences on Computers in Education, WCCE (held approximately every 5 years) have reflected this view. In 1995 we talked of "Liberating the Learner". This phrase was not created lightly. It started as 'liberating the teacher' - then 'liberating the teacher and student', but the Programme Committee were united with the final result of "Liberating the Learner". The reason is clear. If the technologies are not improving the learning process for the student then why are we bothering? In 2001 in Copenhagen our WCCE had the theme "Networking the Learner" and with the number of local area networks (LANs) and wide area networks (WANs) being used in education one can see clearly how this theme applies to more than students networking with each other.

In the 1960s when the 'internet' first appeared and Open Universities were being planned, hopes were high that students could study anywhere: at home, on public transport, in groups, at summer schools, individually, in institutions, in resource rooms. The term 'distance learning' has been with us for thirty years, and yet can we really claim that we have 'liberated the learner' and that Open and Distance learning are really working? Hopefully, at last we can say "YES", though examples are still limited in both number and range. 


\section{WHAT SHOULD WE BE DOING?}

All new technological applications seem to start slowly and many a promoter will claim success when the new system repeats what was previous available 'before computers' albeit that it is same that is now available electronically. How many businesses can survive today by computerising their accounts without the facility of being able to analyse their progress day by day? It is important that every time we use computers we question the added value. Not to the extent that we reject what's on offer, but that we, like good teachers take it further and expect more.

In the last 20 years we have moved a long way in the ease of use remember the overnight processing of the "main frame" and the cassette tape storage of the first Personal Computers. Today, with the inkless pen in our hand and the icons on the screen we are at the stage of the student driving a virtual "exploring space-ship" down through the screen, visiting site after site. There is no need for the student to know whether the data is coming from their machine's hard disk, from the server in the next room, a mainframe across the city, or from the other side of the world. Being able to view on one's Laptop, the changing scene provided by a camera on another continent, as it happens, can certainly add a new dimension to one's study, (e.g. http://www.camcentral.com/)

In a parallel way we can see that successful industries are competing in a global market place and national borders are commercially irrelevant. Information via the Internet does not recognise borders, and education must progress with schools and other institutions sharing a partnership of knowledge.

Education should provide an opportunity for these partnerships to be fully developed, but distance learning has had a slow beginning. As the UK's Open University was developing in the 1970s with its television and radio broadcasts so similar projects were underway in other parts of the world (e.g. The Netherlands, Scandinavia, and Australia). But rarely were other technologies involved and citing examples of good practice where distance learning made use of the new technologies was a difficult task. IFIP's third conference on "Teleteaching" held in Trondheim, Norway in 1993 brought together and published papers on over 100 of best examples of distance learning at that time (Davies \& Samways 1993), though the presentations clearly reflected a lack of progress at school level. However one learnt as much from the failures as from the successes and we should encourage our colleagues to share experiences even when they haven't been a success.

It is interesting to note that at the time of the World Conference on Computers in Education held in 1995 delegates spoke of a 'world wide web' 
and the 'Mosaic' browser program. However, access was still restricted in terms of costs and (learning) time but projects were in progress all over the world. In fact about 40 papers on this topic were selected for presentation at WCCE'95 (Selwood et al. 1995) and these provided a teleteaching conference stream which ran throughout the week of the conference.

In 1996 one of the successful projects for school children, both elementary and secondary, was the "Buddy Project" whereby a 'cuddly toy' was taken by many international delegates (attending the IFIP World Computer Congress) to schools in the Canberra area and these were exchanged for a similar 'buddy' which was taken back to schools in the delegates' countries. Each 'buddy' was cared for by a class of pupils who recorded events in a 'diary'. During the project the two linked schools communicated by e-mail on the internet and after a period of three months the 'buddy' was returned together with the diary and photographs etc. The many successes were due to the pupils having a topic for e-mail communication and the fact that the project had a limited life. But not all exchanges resulted in success, often because a teacher had been allocated the task of managing the project at short notice, or because the two schools were very differently organised.

Another report that deserves a mention is the implementation of TeleNet, a computer network for Teachers which, although developed for teachers of English in Hong Kong, highlights some of the problems and some of the successes that are applicable to all educators (Ki \& Lai 1996). It seems that there is a critical-mass before an on-line conference begins to take off. Another reference is the advice given by Aiken and Aditya (1997) for the effective use of technology in teleteaching. Their golden rule 'Teach unto others as you would like to be taught' and their list of the ten commandments of teleteaching provide good advice for those in undergraduate education.

\section{DEVELOPMENTS AND THE FUTURE}

In the last few years we have seen the number of internet users expand from 10 million to 30 million to 100 million and still increasing. With Web browsers being provided by Netscape and Microsoft, Pentium processors rated at over 1000 Megahertz and broadband connections, access has become so easy and so fast. In fact we are very close to the user not being able to distinguish between data from the PC's own CD-ROM and data from the other side of the world. The virtual "exploring space-ship" referred to earlier in this article. 
Certainly e-mail can be used to transfer materials, tutorials and problem solving exercises along with distant interactions between teacher and learner and between learners themselves, i.e. distance learning. However it must be remembered that projects across countries usually have different aims for different participants. Sometimes it is the global involvement; sometimes the cultural perspectives. In other cases it is environmental issues or the language differences or historical aspects. Access for disabled students in their homes is an extra feature while in-service training for teachers is another option.

\section{HOW FAST IS CHANGE?}

There are many commentators who believe that ICT is bringing about major changes. Bill Gates, for example, in his book "The Road Ahead" foresees a world in which market information will be plentiful and transaction costs low. Others talk of the "end of work" as we know it. All agree that the pace of change is rapid, compared, say to the industrial revolution of the last century. But there are strong reasons why we should believe that the impact of ICT is a greater revolution than we have seen in the past:

- Taking Moore's law that the microprocessor power doubles every eighteen months you can calculate that computer power today costs one hundredth of $1 \%$ what it did in the early 1970 s.

- ICT is all-pervasive - it changes what we do, how we do it, our efficiency, our travel, our taxes, etc.

- It includes 'information' and that is the core to all our business.

- Once developed it can be copied and shared at virtually no cost, except that which the developer decides to charge.

But we must not repeat such views blindly. Development is never uniform and one has only to look at the changes that our parents experienced compared to those that we and our children are experiencing. Consider the products around the home: With the exception of the PC and the video/CD/DVD player, virtually all were around in my childhood, but certainly not of my parent's.

\section{WHAT'S THE EFFECT OF CHANGE?}

In terms of employment the ICT industries are increasing the number of workers, but the actual numbers are far less when you compare Intel with 
General Motors. Ford for example has seventeen times as many employees as Microsoft. The new technologies do increase the efficiency of production of goods and services, but they don't fundamentally change the nature of those products. They do allow us to process the financial side more effectively but this doesn't necessarily increase sales. However it does deliver facilities that were not available before (e.g. the home computer, the internet access) and this is providing a new consumer market. Interestingly in Europe we see 'video' hire shops closing down whereas attendance at cinemas and theatres is on the increase. New restaurants are opening as people "get up and do" things. Sport and leisure centres are thriving and many more people are concerned about their health and ways of better living. Surely this lifelong learning must be due to increased leisure time and receiving greater financial rewards.

\section{WHAT WILL THE FUTURE OFFER?}

ICT will improve the effectiveness of our companies. It may not reduce our workforce but it will make us more efficient. No longer will we have to correct previous mistakes; no longer will goods be delivered wrongly. Our time will be used more economically as 'waste' is reduced and customers will benefit from the 'added-value'. Individually we shall have the world's information at our finger tips. A single press on our mobile communicator will bring us the latest news, sports, company data, share prices. A quick digital electronic search will provide answers which previously would have taken a visit to a library or several phone calls. Using previously unproductive time such as train or plane journeys where 'input' was not previously possible, allows us more time to do those things we enjoy.

Of course we shall need less typists, bank cashiers, book-keepers and telephone operators, but the demand for computer specialists, for health carers, for teachers, for nurses, for chefs will increase. The move is to hitech and hi-touch services which are the things that people enjoy and will be able to afford. But note that those careers and professions where there is a demand are changing ones and this means that training and education has to be on-going. We have to subscribe to lifelong learning.

The ICT will change - larger images on easily-scrollable, small screens, on-line access anywhere, faster communications, and lower costs - and as always it will be commercially-led. Just as the mobile phone has limited memory but access to good connecting and processing facilities so our "Tablet PC" will soon offer us the ICT power we need wherever we are. In fact following the 'laptop with a phone inside' and the personal PDA, it could well replace the mobile phone for many users. Some people will make a 
fortune in those areas where ICT can actually create new categories of consumer demand (e.g. learning packages and entertainment products) and if you can do this I wonder why you are reading this and not getting started.

\section{HOW TO GET STARTED}

It seems so straight-forward to connect a school to the internet. First you need a line, a telephone or cable connection, and a modem or a network card inside (or outside) your computer. Pay an Information Service Provider (ISP) for the link and that completes the facility and the school is connected. Clearly there is a need for a network inside the school if more than one machine and more than one person is to use the facility. And the facility supports the whole curriculum so all classrooms have to be connected and then there is a requirement for additional equipment such as Laptops, Interactive whiteboards, mobile communications. And if there are more users then the line has to be faster......... And so on.

\section{WHAT ARE THE BENEFITS}

As the reader will know the school's own network (LAN) will allow:

- E-mail connection to others within the institution, within the community and throughout the world;

- Access to their intranet and the world wide web;

- Sharing of resources (printers, software, files etc.).

But it can also free up time for teaching and learning. However, many companies computerise their records but to no real advantage except they can make changes more quickly. Schools, like companies, have to be managed and the management decisions need to be based on facts - data that the system can provide, and I would emphasise that you cannot separate curriculum from management.

All schools have to go through development stages, but those not at the leading edge need not make the mistakes if good practice is shared. Just as in a company, one must ask "What are the benefits that we are trying to achieve". Here might be my list:

- To raise standards (More efficient learning and at a greater rate);

- Anytime, anywhere learning (AAL);

- Provision of accurate knowledge;

- ICT confident and competent teacher (Curriculum and Management);

- ICT qualified teachers; 
- ICT certified school leavers;

- Efficient electronic schools, local councils and governments.

From the school's point of view this requires a commitment of staff, pupils and parents - a whole ICT school policy with a shared understanding of aims.

Others have defined the factors for successful implementation (for example see Becta, 1999) but the list should include:

1. Agreement of the aims by staff, pupils, parents;

2. The integration of ICT into classroom practice;

3. Allocation of appropriate resources;

4. Teacher understanding of the benefits of ICT;

5. Reliable and timely technical support;

6. Realistic replacement plans.

Taking the first of these six factors it is clear that there is much preparation to be done. At what stage is the school currently in terms of ICT? Just starting, or established, or confident? And what of the staff? Are they just starting with ICT, or established or confident? Most schools would have a mixture, but what of those schools where all staff are just starting?

So clearly the school needs a 'plan of action', and this might be a three or five year plan, but it is important that all agree the type of establishment that they want their school to become. In the UK the National College for School Leadership NCSL)(DfES 2003) has developed an initial framework for ten key features of the "e-confident schools". These can be briefly summarised as:

1. ICT competent staff;

2. Effective use of ICT in learning and teaching;

3. Comprehensive managed learning systems;

4. Effective management information system;

5. Continuing professional development;

6. Decisions based on sound data;

7. Appropriate funding for ICT;

8. On demand access and support;

9. Pupils having high ICT capability;

10. The school as the community hub.

In the past item 7, the cost and the source of funding is usually the first item raised. Thankfully many governments have introduced grants to assist schools to move forward, but there are many additions to the PCs and Laptops that are required if ICT is to become integrated across the curriculum. Scanners and printers require paper. Whereas digital still and 
movie cameras cost hundreds of Euros, data projectors and interactive whiteboards cost several thousands. In a variety of ways schools are achieving funding and their greatest concern has moved to item 1, the need for staff confidence, competence and leadership in ICT. The 'Strategic Leadership of ICT' programme (SLICT) is designed to meet this demand in the UK. (www.ncsl.org.uk/slict).

\section{OTHER COSTLY ITEMS}

If youngsters seem to cope so easily with ICT why can't our teachers? They are not so competent even after the in-service training (professional development) programmes of the last few years. There are many for whom the technology is still a frightening thought and although they have some experience they feel far from competent. At least they have moved from not knowing they were incompetent in ICT, to knowing their shortfalls in ICT. As nations we must continue to train our teachers, provide more classroom support and ensure that newly-qualified teachers entering the profession are competent. Hence we move to an ICT competent profession. But such a profession needs to be well supported. Supported in terms of technical support (maintenance, upgrades, suppliers etc); in terms of software (advice, suppliers, installation); in terms of training (courses, qualifications, conferences); and not least in terms of status (job prospects, remuneration, professional development).

\section{WHERE ARE WE GOING?}

No longer will schools 'look after children' whilst parents are at work. Nor will teachers advise on which vocations to follow (Miller \& Bentley 2002). Classrooms of, say, 8 years times will not be recognisable to the teacher of today. Firstly the teacher's role will be to advise on various networks of learning and knowledge and to prepare pupils to "manage their learning". The 50 minute group lesson period will be replaced by one-to-one tuition, but not necessarily face-to-face. Learning opportunities will be available 24 hours a day on-line together with an on-line teacher, tutor or mentor. Schools will become the local hub of learning, bringing together parents, local residents and public agencies to offer community-wide learning opportunities. In this way teachers will take a major role in shaping the society in which we live just as they did in the $19^{\text {th }}$ and $20^{\text {th }}$ centuries. So maybe it is not just a matter of connecting schools. What about broadband connections to the libraries, the youth clubs and, of course the home, so that 
the youngsters can access their work from a variety of locations? There are several examples of pupils getting their course at home from the school web pages and having to e-mail their work to the teacher for marking. See:

- http://www.cornwallis.kent.sch.uk A GNVQ course in ICT;

- http://www.ninestiles.bham.sch.uk A year 7/8 science course.

Both schools have gone to wireless technology for their school networks and the children, well more exactly their parents, pay for the pupil's individual laptop. These are 'leased' at so much per week as a group scheme through the scheme with special consideration for 'poorer' families and those with more than one child. Not $100 \%$ take up but over $90 \%$ in one case and $75 \%$ in the other, with those without either, borrowing from the school or sharing a friend's at home. In terms of connecting schools and the robust 'fire-wall' for unwanted material, here we have examples of an additional problem in that pupils need to access school pages from outside the school.

\section{CONCLUSION}

I think my greatest worry is not that we won't succeed and achieve my list of benefits, but that we may waste much time and money in going in the wrong direction. Advice is offered by so many different agencies, some providing only a partial picture and our schools need help to ensure all the benefits are realised and that the successes of others around the world are shared to the advantage of all learners. In becoming 'e-confident', there are many considerations for schools to take into account; number of pupils, number of systems, locations, staff training, software access, maintenance, networks, curriculum systems, management systems, etc and poor advice will certainly affect a sizeable community, if not a whole nation.

\section{REFERENCES}

Aiken, R.M. \& J. N. Aditya (1997) The Golden Rule and the Ten Commandants of teleteaching: harnessing the power of technology in education. In Collis. B. and B. Samways (eds.) Education and Information Technologies, Vol 2, No. 1, Chapman \& Hall.

Becta (1999) Connecting Schools, Networking People 2000. Becta, Coventry, UK.

Davies, G. \& B. Samways (1993) Teleteaching. North-Holland, Amsterdam.

DfES, (2003) Fulfilling the Potential. DfES, London. 
Ki, W-W. \& K-W. Lai (1996) Computer-mediated communication and teacher education: some observations from the implementation of TeleNex. In Collis. B. \& B. Samways (eds.) Education and Information Technologies, Vol. 1 No. 2, Chapman \& Hall.

Selwood, I., P. Fox \& M. Tebbutt (Eds.) (1995) Conference Abstracts - Sixth World Conference on Computers in Education. IFIP Technical Committee 3, International Federation for Information Processing, Laxenburg, Austria.

Miller, R. \& T. Bentley (2002) Unique Creation, National College for School Leadership, United Kingdom. 